\title{
The expression of scavenger receptor B2 in enterovirus 71-infected mice
}

\author{
Ji-an Li and Zong-bo Chen* \\ *Correspondence: chenzbdr001@163.com

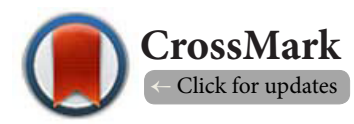 \\ Pediatric Department of the Affiliated Hospital of Qingdao University Medical School, NO.16 Jiangsu, Road, Qingdao 266003, PR China.
}

\begin{abstract}
Objectives: Scavenger receptor class B, member 2 (SCARB2) participates in early innate immune responses to infection, so our aim was to explore the expression and role of mouse SCARB2 (mSCARB2) in different tissues in EV71-infected mice.

Methods: ICR mice were inoculated intraperitoneally (i.p.) with EV71 $0.1 \mathrm{ml} 10^{7.5} \mathrm{TCID}_{50} / \mathrm{ml}$. The control mice were injected i.p. with the same volume RD cell lysate. Mice were sacrificed by aether anesthesia at day 4, 8 and 12 post infection (p.i.), their brain, brainstem, spinal cord, cerebellum, lung and heart were dissected out for determining the number of copies of viral RNA by quantitative real-time PCR (qRT-PCR), detection of expression of mSCARB2 by immunohistochemistry, qRT-PCR and Westernblotting. Cytokines quantification by ELISA.

Results: The viral loads in central nervous system (CNS) were higher than in lung or/and heart. The expression of mSCARB2 increased in tissues of EV71-infected mice, however, the levels of mSCARB2 increased in CNS were higher than in lung or/and heart within a certain period of time, particularly in brainstem and brain. In addition, local TNF- $\alpha$, IL- 6 and IL-1 $\beta$ levels of production were consistent with mSCARB2 levels of expression in tissues of EV71-infected mice. However, it presented a positive correlation between relative mSCARB2 mRNA level and TNF- $\alpha$, IL- 6 and IL-1 $\beta$ levels in local tissues at day 4 and 8 p.i..

Conclusions: Our data revealed that the elevated local mSCARB2 may modulate pro-inflammatory cytokines induction in local tissues, particularly, in CNS of EV71-infected mice.
\end{abstract}

Keywords: Enterovirus 71, mice, mSCARB2, pro-inflammatory cytokines

\section{Introduction}

Enterovirus 71 (EV71), a neurotropic virus with undefined pathogenesis, has caused significant morbidity and mortality throughout the world, especially in the Asia-Pacific region since it was first detected in 1969 in the United State [1,2], including Singapore [3,4], South Korea [5], Malaysia [6], Japan [7], Vietnam [8], and China [9,10]. EV71, together with coxsackievirus A 16 (CVA16) infections are generally associated with hand, foot and mouth disease (HFMD), but EV71 infection occasionally progress to severe neurological disease, including aseptic meningitis, poliomyelitis-like paralysis, and possibly fatal encephalitis in neonates, especially brainstem encephalitis associated with pulmonary edema and cardiac insufficiency were the primary manifestations in patients with neurologic involvement $[11,12]$. Numerous animal models have been developed to study the pathogenesis of EV71 infection using the mouse-adapted strain of EV71 [13,14], innate immunodeficient mice [15]. The EV71 BrCr strain was demonstrated to induce neurological manifestation of tremor, ataxia, and brain edema in cynomolgus monkeys [16]. Moreover, EV71 BrCr infected mice also developed limbs paralysis and encephalitis [17].

SCARB2 (also known as Lysosomal Integral Membrane Protein II, LIMP II, LGP85 or CD36b like-2) is composed of 478 amino acids and belongs to the CD36 family, which includes CD36 and scavenger receptor $B$, member 1 (SR-B I and its splicing variant SR-B II $[18,19]$. SCARB2 is one of the most abundant proteins in the lysosomal membrane and participates in membrane transportation and the reorganization of the endosomal/ lysosomal compartment [19-21]. SCARB2 shuttles between these compartments and the plasma membrane [19]. SCARB2 is a type III double-transmembrane protein with a large extracellular domain (when it is present at the cell surface) and short cytoplasmic domains at the amino- and carboxy-terminus [18]. SCARB2 is expressed in a variety of tissues, including neurons in the CNS. SCARB2 deficiency in mice causes ureteric pelvic junction obstruction, deafness, and peripheral neuropathy, and SCARB2 deficiency in humans causes action myoclonus-renal failure syndrome (AMRF) $[\mathbf{2 2 , 2 3 ]}$. The role of SCARB2 appears to be connected to the TNF-a-dependent and early activation of Listeria macrophages through internal signals linking the regulation of late trafficking events with the onset of the innate Listeria immune response [24].

Animal models have been developed to detail the pathogenesis of EV71 infection. However, the majority of the research has been devoted to understanding the neurotropism and neuropathogenesis of EV71, whereas the immunopathogenesis 
aspect of the viral infection has remained largely unknown. It was proposed that overwhelming virus replication combined with the induction of massive pro-inflammatory cytokines is responsible for the pathogenicity of EV71 [25-27]. Indeed, high levels of interleukin-1 $\beta$ (IL-1 $\beta$ ), IL-6, IL-10, IL-13, gamma interferon (IFN- $\gamma$ ), and tumor necrosis factor alpha (TNF- $\alpha$ ) in the serum and cerebral spinal fluid (CSF) from EV71infected patients have been consistently reported $[\mathbf{2 5}, \mathbf{2 7}, \mathbf{2 8}]$. In particular, CSF levels of IL-1 $\beta$, IL- 6 , and TNF- $a$ were found significantly elevated in patients with pulmonary edema (PE) and encephalitis, demonstrating a strong correlation between pro-inflammatory cytokine production and clinical severity in EV71 infections [26,29], and in EV71-infected neonate mouse model sustained high levels of IL-6 [30]. SCARB2-deficient mice display a macrophage-related defect in Listeria innate immunity. They produce less acute phase pro-inflammatory cytokines/chemokines, MCP-1, TNF- $\alpha$, and IL- 6 , but normal levels of IL-12, IL-10, and IFN- $\gamma$ and 25 -fold increase in susceptibility to Listeria infection [24].

In this study, we assessed the expression of SCARB2 and the production of pro-inflammatory cytokine during EV71 infection in the neonatal mouse. Our results indicate that EV71 infection leads to the expression of SCARB2 increased in different tissues, which correlated with the local elevated levels of pro-inflammatory cytokine induction, especially in CNS.

\section{Materials and methods}

\section{Cells and viruses}

Human Rhabdomyosarcoma (RD) cells (purchased from the Chinese Academy of Sciences Cell Bank, Shanghai, China.) were maintained in Dulbecco's Modified Eagle's Medium (DMEM, Gibco) containing 10-15\% fetal bovine serum (FBS, Gibco), $2 \mathrm{mM}$ L-glutamine, $100 \mathrm{IU}$ of penicillin, and $100 \mu \mathrm{g}$ of streptomycin $/ \mathrm{ml}$ at $37^{\circ} \mathrm{C}, 5 \% \mathrm{CO}_{2}$. Non-mouse-adapted EV71 strain $\mathrm{BrCr}$ (a kind gift from Institute of Medical Biology, Chinese Academy of Medical Sciences \& Peking Union Medical College, Kunming, China.) was propagated in RD cells. Once the cells displayed cytopathic effect (CPE), they were harvested, and cellular debris was removed by centrifugation at $10,000 \times \mathrm{g}$ for $30 \mathrm{~min}$. To prepare virus stocks, virus were propagated for one more passage in RD cells. The virus was purified by Amicon ${ }^{\circledR}$ Ultra $100 \mathrm{~K}$ device (Millipore) at 4,000 $\times \mathrm{g}$ for $40 \mathrm{~min}$. The $50 \%$ tissue culture infective dose $\left(\mathrm{TCID}_{50}\right)$ was determined in RD cells using the Reed and Muench formula [31], and working virus stocks at $10^{7.5} \mathrm{TCID}_{50}$ per $\mathrm{ml}$.

\section{Animals and treatments}

ICR mice ( purchased from Laboratory Animal \& Animal Experiment Center, Qingdao, China). They were housed under specific-pathogen-free conditions, housing temperature at $23^{\circ} \mathrm{C}$. All institution guidelines for animal care and use were strictly followed throughout the experiments. One-day-old ICR mice were inoculated i.p. with EV71 $0.1 \mathrm{ml} 10^{7.5} \mathrm{TCID}_{50} / \mathrm{ml}$. The control mice were injected i.p. with the same volume RD cell lysate and kept in separate cages. Their weight gain or loss and clinical signs, including ruffled fur, hunchback, wasting, limb weakness, limb paralysis, twitch, moribund and death were monitored daily up to 14 days after inoculation. The clinical score was graded as follows: 0 , healthy; 1 , weakness in hind limbs; 2, paralysis in a single limb; 3, paralysis in more than two limbs; 4, death [32]. In addition, mice per group were sacrificed by aether anesthesia at day 4,8 , and 12 post infection, respectively. After perfusion with PBS containing EDTA, their brain, cerebellum, brainstem, spinal cord, heart and lung were immediately dissected out for the extraction of RNA, for the extraction of protein or for immunohistochemical examinations, respectively. The experimental protocol was approved by the Animal Care and Use Committee of the Institute of Laboratory Animal Science of Chinese Academy of Medical Sciences.

\section{Virus detection in mice}

For this study, quantitative real-time PCR (qRT-PCR) was used to determine the number of copies of viral RNA present in detected tissues. Total RNA was extracted from individual brain, cerebellum, brainstem, spinal cord, heart and lung using an RNAiso Plus Kit (Takara, Dalian, China) according to manufacturers' instruction. Next, total RNA was reverse-transcribed with random hexamers using a Reverse Transcription kit (Thermo Scientific). The cDNA was subjected to quantitative PCR in a $50-\mu l$ reaction mixture (Thermo Scientific DyNAmo SYBR Green qRT-PCR Kit) with primers of EV71-S (5'-GCAGCCCAAAAGAACTTCAC-3') and EV71-A (5'-ATTTCAGCAGCTTGGAGTGC-3') for EV71/BrCr of nucleotides 2372-2598 [14,33], and the conditions consisted of a denaturation step at $95^{\circ} \mathrm{C}$ for $15 \mathrm{~min}$ and 40 cycles of thermal cycling of $95^{\circ} \mathrm{C}$ for $10 \mathrm{~s}$ and $60^{\circ} \mathrm{C}$ for $60 \mathrm{~s}$. The EV71 virus fragment of nucleotides $2372-2598$ was used as real-time PCR standard by adjusting to a concentration gradient of $1 \times 10^{7}$ copies $/ \mu \mathrm{l}, 1 \times 10^{6} \mathrm{copies} / \mu \mathrm{l}, 1 \times 10^{5} / \mu \mathrm{l}$, and $1 \times 10^{4} \mathrm{copies} / \mu \mathrm{l}$, and the DNA fragment with known copies was used as standard to calculate the copy number of virus RNA in the infected tissues. Quantitative real-time RT-PCR was performed using the Mxpro-Mx3000P system.

\section{Immunohistochemical staining}

The tissues from sacrificed mice were rinsed in $10 \%$ buffered formalin and then embedded in paraffin. Four micrometer sections were slided (Leica RM 2235) and placed on poly-L-lysine-coated glass slides before fixing with $3.7 \%$ paraformaldehyde. The sections were blocked by endogenous peroxidase for $10 \mathrm{~min}$, nonspecific protein binding sites were also blocked for $10 \mathrm{~min}$. The sections were incubated with mSCARB2 antibody (Abcam ${ }^{\circledR}$ discover more) 1:100 for $1 \mathrm{~h}$, and then were incubated with secondary antibody IgG-Biotin and Streptavidin-HRP (Streptavidin-HRP Kit, CWbio.Co.Ltd, Beijing, China) for 10 min at room temperature, respectively. A red to brown peroxidase stain was developed using the 
DAB Chromogenic Reagent kit (CWbio.Co.Ltd, Beijing, China), and the sections were examined with a light microscope after counterstaining with hematoxylin.

\section{Detection of mSCARB2 gene expression}

To examine mSCARB2 expression, total RNA from different tissues of EV71-infected mice and controls using an RNAiso Plus Kit (Takara, Dalian, China) following the manufacturer instructions were isolated. Total RNA was converted into cDNA by the reaction of reverse transcription (RT) using a Reverse Transcription kit (Thermo Scientific). The cDNA was subjected to quantitative PCR (Thermo Scientific DyNAmo SYBR Green qRT-PCR Kit) with a Rotor-Gene RG-3000 System. The primers were mSCARB2-L1 (5'-TCTGCTGTCACCAATAAGGC-3') and mSCARB2-R1 (5'-CCAGATCCACGACAGTCAAC- $\left.3^{\prime}\right)$. The conditions consisted of a denaturation step at $95^{\circ} \mathrm{C}$ for $15 \mathrm{~min}$ and 40 cycles of thermal cycling of $95^{\circ} \mathrm{C}$ for $10 \mathrm{~s}$ and $60^{\circ} \mathrm{C}$ for $60 \mathrm{~s}$. The GAPDH was used as an internal control. The relative gene expression was calculated using the $2^{-\Delta \Delta C t}$ as described previously [34]. Each sample was run in triplicate.

\section{Western blot analysis}

For Western blot analysis of mSCARB2 in the various tissues, each sample was homogenized in ice-cold tissue extraction buffer (Invitrogen, Carlsbad, CA) containing 1\% protease in hibitor cocktail. The homogenates were centrifuged at $11000 \times \mathrm{g}$ for $30 \mathrm{~min}$ at $4^{\circ} \mathrm{C}$. The BCA protein assay kit (PIERCE, UK) was used to assay the total protein of each sample. Samples with equal protein concentrations, were loaded onto an $8 \%$ SDSPAGE. After electrophoresis, the proteins in the gels were transferred electrophoretically onto polyvinylidene fluoride membranes. Excess sites on the membrane were blocked by incubation for $2 \mathrm{~h}$ at room temperature, with 3\% (wt/vol) nonfat dried skimmed milk in $20 \mathrm{mM}$ Tris- $\mathrm{HCl}, \mathrm{PH} 7.5$, and 150 $\mathrm{mM} \mathrm{NaCl}$ (Tris-buffered saline [TBS]). After a single washing with TBS, the membranes were incubated with anti-mSCARB2 antibodies (Abcam ${ }^{\circledast}$ discover more) 1:100 in TBS/0.05\% Tween 20 by incubation overnight at $4^{\circ} \mathrm{C}$. The membranes were then washed three times with TBS $/ 0.05 \%$ Tween 20 , and incubated with $0.3 \mu \mathrm{g} / \mathrm{ml}$ horseradish-peroxidase-labeled anti-rabbit IgG (Biosource) in 3\% (wt/vol) nonfat dried skimmed milk in TBS for $1 \mathrm{~h}$, at room temperature. Immunoreactive proteins were visualized with an enhanced chemiluminescence detection system (ZSJQ Corp., Beijing, China) according to the manufacturer's instruction. The amounts of mSCARB2 proteins were expressed relative to those of the amount of GAPDH.

\section{Cytokine quantification}

Various tissues were harvested from sacrificed animals at indicated time point, weighed, and homogenized in 500 $\mu \mathrm{l}$ of $1 \times$ phosphate-buffered saline (PBS) immediately. The homogenates were centrifuged at $13,000 \times \mathrm{g}$ for $10 \mathrm{~min}$ at $4^{\circ} \mathrm{C}$, and the supernatant was collected and stored frozen at $-80^{\circ} \mathrm{C}$ until further analysis. The levels of cytokines were measured using a Solid Phase Sandwich ELISA kits (Mouse TNF- $\alpha$, IL- 6 and IL-1 $\beta$ Quantikine, R\&D Systems), and following the manufacturer's instructions. Sensitivities of the TNF- $a$, IL-6 and IL-1 $\beta$ assays according to manufacturer protocol were $7.21 \mathrm{pg} / \mathrm{ml}, 1.8 \mathrm{pg} / \mathrm{ml}$ and $4.8 \mathrm{pg} / \mathrm{ml}$, respectively. Intraassay and interassay coefficients of variation were: TNF-a: $3.9 \%$ and 6.2\%; IL-6: 3.9\% and 8.9\%; IL-1 $\beta: 4.6 \%$ and $6.6 \%$.

\section{Statistical analysis}

All statistical analyses were done with GraphPad Prism, version 5.0 (GraphPad 4 Software, San Diego, CA), for Mac. KaplanMeier survival curves were analyzed by a log rank test. Clinical score curves were analyzed by the Kruskal Wallis test. Other experiments were analyzed by Student's $t$ test or by one-way analysis of variance (ANOVA) followed by Tukey's multiple comparison tests. Pearson's correlation was used to analyze the relation between pro-inflammatory cytokines and mSCARB2. A P-value of $<0.05$ was considered as statistically significant.

\section{Results \\ EV71 Infection in mice}

The mice infected with virus were monitored daily for 14 days after inoculation with virus. In this study, infected mice developed severe symptoms. Fatigue in the hind limbs occurred at day 1-2 p.i., followed by paralysis in a single limb or/and paralysis in more than two limbs at days 3-7 p.i., or showed other signs of encephalitis such as hunched posture, lethargy, or ataxia, and death occurred at 2-7 p.i.. The healthy mice in the cell lysate control group was no a single mouse dead. Among the observed three groups $(A, B, C)$, the survival curves were no significantly different (Figure 1A). But 7-8 days later, the survivors' symptoms gradually restored. In the three groups $(A, B, C)$, the clinical scores were no significantly different (Figure 1B). However, their body weights appeared to grow slowly.

EV71 Strain BrCr Displays Neurotropism in ICR mice At day 1 p.i., viral RNA were only detected in spinal cord, but were not detected in brainstem, cerebellum, brain, heart and lung. The number of copies of EV71 RNA detected at day 4 p.i. were in lung ( $3.99 \pm 0.13 \log _{10}$ copies/mg tissue), heart (3.11 $\pm 0.12 \log _{10}$ copies/mg tissue), brain (5.31 $\pm 0.30 \log _{10}$ copies/mg tissue), brainstem ( $6.17 \pm 0.18 \log _{10}$ copies/mg tissue), spinal cord (5.59 $\pm 0.12 \log _{10}$ copies/mg tissue), and cerebellum ( $4.51 \pm 0.26 \log _{10}$ copies/mg tissue), however, the virus was gradually eliminated (Figures 2A-2F). A histopathological examination of the infected mice in different time was carried out. Marked lesions and/or obvious signs of inflammation were observed for the brain, brainstem, spinal cord, cerebellum, but heart and lung showed less lesions and/or signs of inflammation (data not shown).

Different Tissues of EV71-infected Mice Express mSCARB2 Expectedly, mSCARB2 immuno-reactivity was not only 

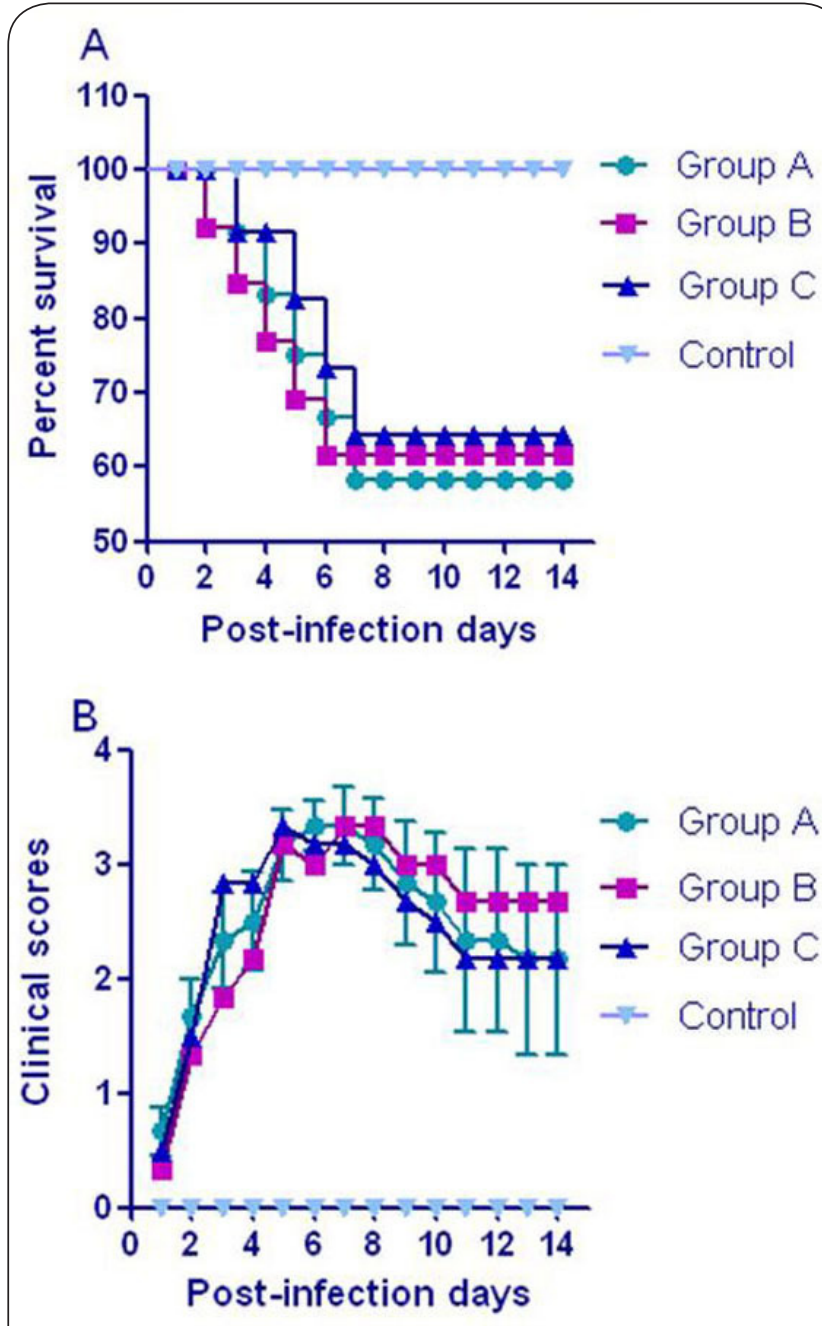

Figure 1. One-day-old ICR Mice Were Inoculated i.p. with EV71. The survival rates (A) and clinical scores (B) of the infected mice (a group, $n=6$ ) were monitored over a 14-day period. Results are representative of 3 independent experiments.

observed in lung, heart, brain, brainstem, spinal cord and cerebellum cells, but also the obvious immuno-reactivity was observed at day 4 p.i. compared to controls, and gradually decreased in later days (Figure 3). These results suggested that expression of $\mathrm{mSCARB} 2$ increased in these tissues after mice with EV71 infection.

In this study, we found that the mSCARB2 mRNA levels elevated in all selected tissues at day 4 p.i., but the mSCARB2 mRNA levels were higher in brainstem $(P<0.001)$, brain $(P<0.01)$, spinal cord $(P<0.01)$ and cerebellum $(P<0.05)$ than in lung or/and heart. However, at day 8 p.i., the mSCARB2 mRNA levels obviously decreased, still in brainstem $(P<0.001)$, brain $(P<0.05)$ were higher compared to lung or/and heart. At day 12 p.i., only the mSCARB2 mRNA level in brainstem were observed higher than in lung or/and heart $(P<0.05)$ (Figure 4A). Figure 4A also showed that the mSCARB2 mRNA levels in
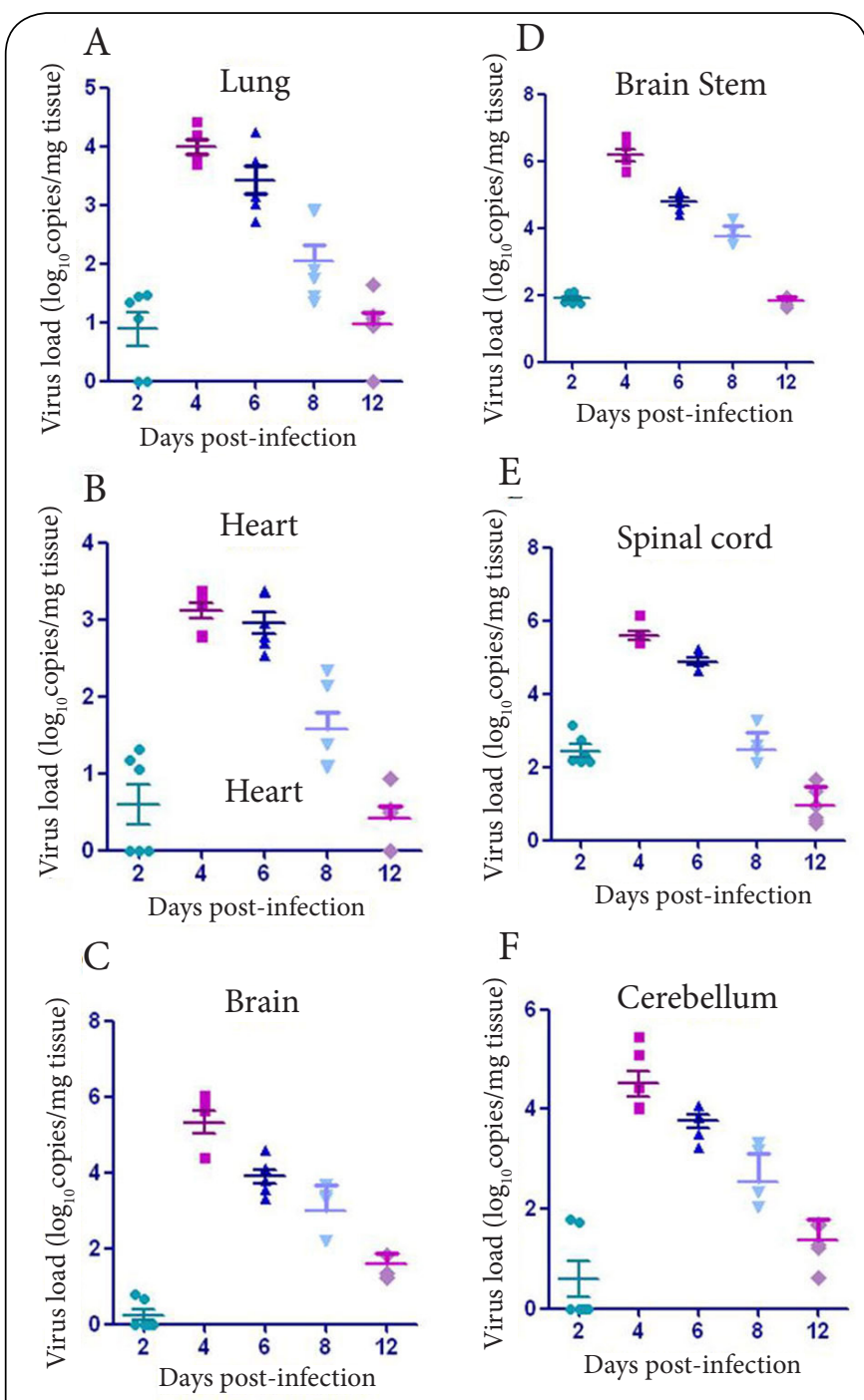

Figure 2. Virus Loads in Tissues from ICR Mice Infected with EV71 via The i.p. Route. One-day-old mice were inoculated i.p. with EV71. At day 2, 4, 6, 8 and 12 p.i., animals $(\mathrm{n}=6)$ were euthanized, and virus titers in the lung (A), heart (B), brain $(\mathbf{C})$, brainstem (D), spinal cord (E), and cerebellum (F) were determined by qRT-PCR. Results are expressed as Log viral RNA copies per milligram of tissue and values are means \pm SEM of triplicate experiments.

brainstem and brain were higher than in spinal cord and cerebellum. These results suggest that the expression of mSCARB2 increased obviously in CNS of EV71-infected mice, especially, in brainstem and brain (Figure 4A).

The expression of mSCARB2 protein showed moderate signals ( 70 85 KDa band) at day 4 p.i. in brainstem, brain, spinal cord, cerebellum, lung and heart, weaken band at day 8 and 12 p.i., and controls. These results further conformed the mSCARB2 gene expression tested by qRT-PCR. The protein expression of $\mathrm{mSCARB} 2$ had the similar trend with gene expression (Figures 4B-4E). 


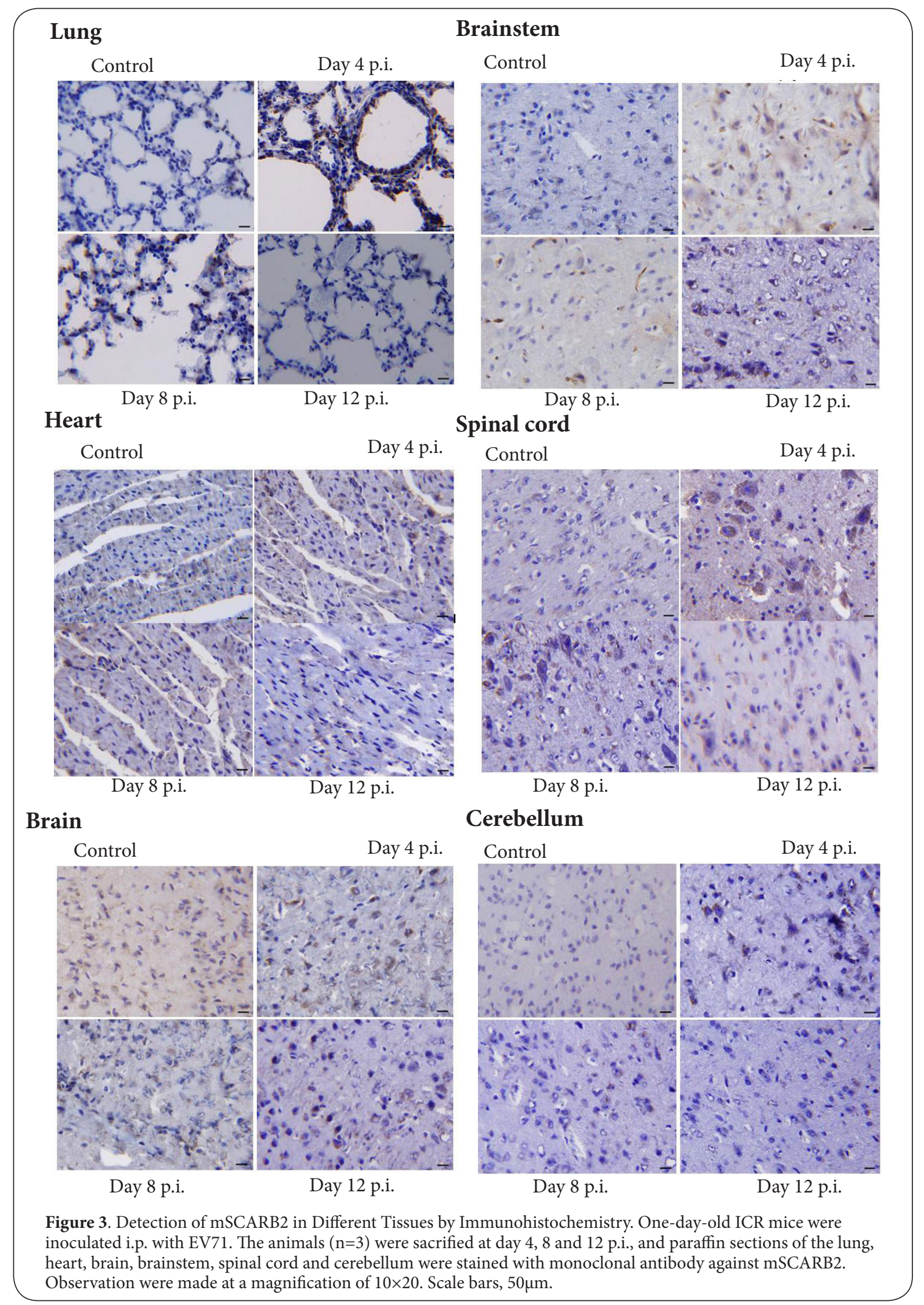




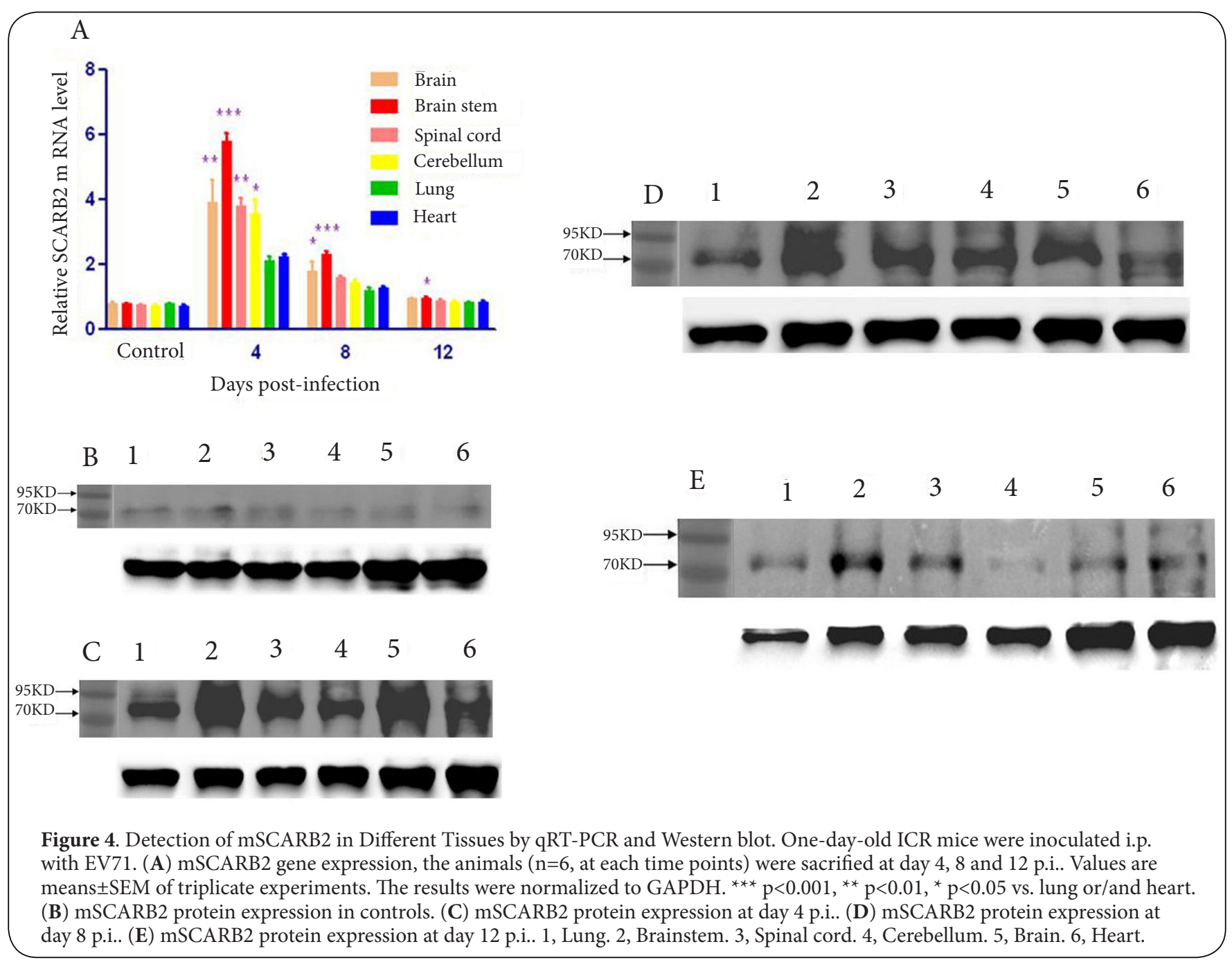

Local Levels of Pro-inflammatory cytokines were elevated in EV71-infected mice

Enhanced cytokine production has been proposed to contribute to EV71 pathogenesis in both humans and mice $[26,28,30]$. Local TNF- $\alpha$, IL- 6 and IL- $1 \beta$ levels were significantly higher in the various tissues homogenates prepared from EV71-infected animals at day 4 p.i. than in those from agematched noninfected controls. Meanwhile, TNF- $a$, IL- 6 and IL-1 $\beta$ levels were significantly higher in CNS (brain, brainstem, spinal cord and cerebellum) than in lung or/and heart (Figures 5A-5C). At day 8 p.i., these pro-inflammatory cytokines levels decreased in all tested tissues, but still higher in CNS than in lung or/and heart (Figures $\mathbf{5 A - 5 C}$ ), and at day 12 p.i., these pro-inflammatory cytokines further declined, however, IL-6 and IL-1 $\beta$ levels in brainstem and brain presented higher compared to in lung or/and heart (Figures $5 \mathrm{~A}-5 \mathrm{C}$ ).

In this study, we found that local mSCARB2 expression were consistent with TNF- $\alpha$, IL- 6 and IL-1 $\beta$ production in the brain, brainstem, spinal cord, cerebellum, lung and heart from EV71-infected mice. Surprisingly, it presented a positive correlation between relative $\mathrm{mSCARB} 2 \mathrm{mRNA}$ level and TNF- $\alpha, \mathrm{IL}-6$ and IL- $1 \beta$ levels in local tissues at day 4 p.i. and at day 8 p.i., till at day 12 p.i., it showed no correlation (Table 1). These results suggested that the elevated pro-inflammatory cytokines in a certain range in local tissues induced higher expression of mSCARB2.

\section{Discussion}

We have demonstrated that one-day-old ICR mice were infected by the $\mathrm{EV} 71 \mathrm{BrCr}$ strain in vivo, and we used these models to assess the expression of mSCARB2 in CNS, lung and heart. The survival rates and clinical scores of infected mice were used to measure clinical symptoms or activities. After infection with EV71, virus was detected within various tissues by qRT-PCR. Our results indicated that one-day-old ICR mice are susceptible to EV71 infection and develop into CNS infection, as observed for humans. Upon infection via the peritoneal route, ICR mice consistently displayed hunchback, 


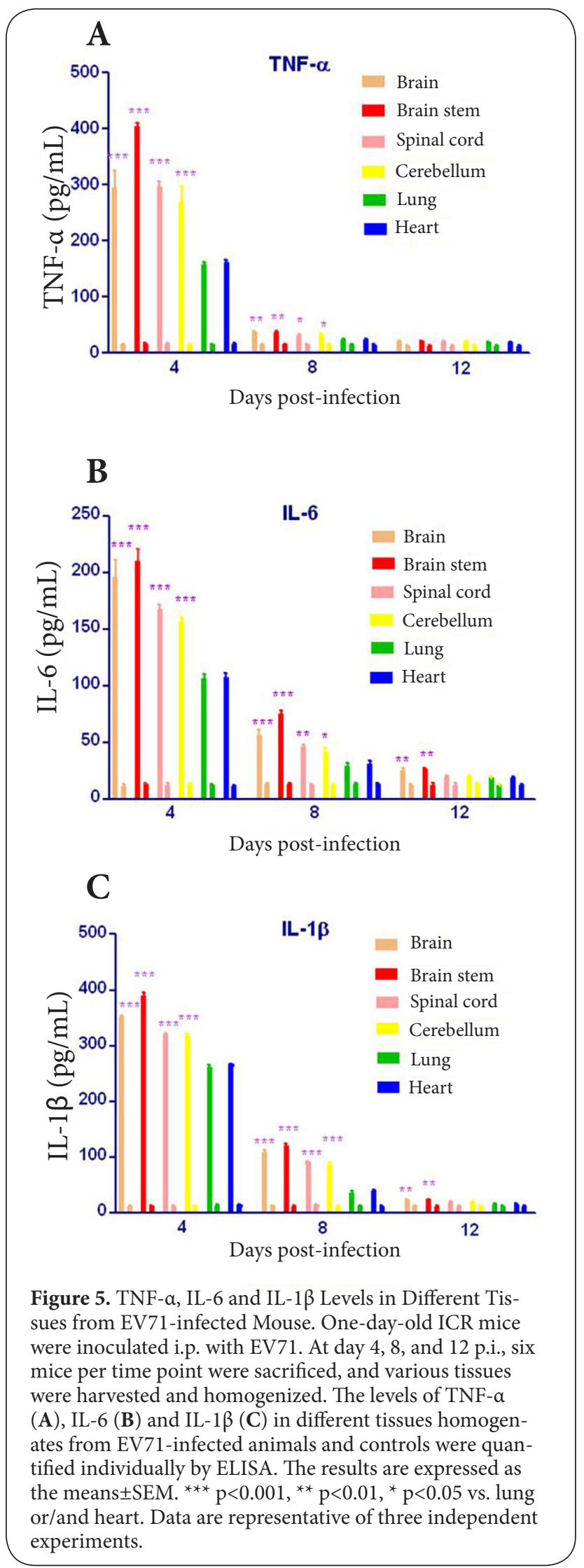

Table 1. Correlations of local levels of pro-inflammatory cytokines and expression of mSCARB2 in EV71-infected mice.

\begin{tabular}{|c|c|c|c|c|c|c|c|}
\hline \multirow[t]{2}{*}{ Time } & \multirow{2}{*}{$\begin{array}{l}\text { Cytokines/ } \\
\text { tissues }\end{array}$} & \multicolumn{6}{|c|}{ mSCARB2 Pearson correlation/Significance (two-tailed) } \\
\hline & & Brainstem & Brain & $\begin{array}{l}\text { Spinal } \\
\text { cord }\end{array}$ & Cerebellum & Heart & Lung \\
\hline \multirow[t]{3}{*}{$\begin{array}{l}\text { Day } 4 \\
\text { p.i. }\end{array}$} & $\begin{array}{l}\text { TNF- } \alpha \\
(\mathrm{pg} / \mathrm{mL})\end{array}$ & $\begin{array}{l}0.933 \\
0.007\end{array}$ & $\begin{array}{l}0.829 \\
0.041\end{array}$ & $\begin{array}{l}0.899 \\
0.015\end{array}$ & $\begin{array}{l}0.825 \\
0.043\end{array}$ & $\begin{array}{l}0.989 \\
<0.01^{\text {a }}\end{array}$ & $\begin{array}{l}0.913 \\
0.011\end{array}$ \\
\hline & $\begin{array}{l}\text { IL-6 } \\
(\mathrm{pg} / \mathrm{mL})\end{array}$ & $\begin{array}{l}0.958 \\
0.003\end{array}$ & $\begin{array}{l}0.693 \\
0.127\end{array}$ & $\begin{array}{l}0.861 \\
0.028\end{array}$ & $\begin{array}{l}0.903 \\
0.014\end{array}$ & $\begin{array}{l}0.989 \\
<0.01^{\mathrm{a}}\end{array}$ & $\begin{array}{l}0.920 \\
0.009\end{array}$ \\
\hline & $\begin{array}{l}\text { IL-1 } \beta \\
(\mathrm{pg} / \mathrm{mL})\end{array}$ & $\begin{array}{l}0.955 \\
0.003\end{array}$ & $\begin{array}{l}0.830 \\
0.041\end{array}$ & $\begin{array}{l}0.918 \\
0.010\end{array}$ & $\begin{array}{l}0.910 \\
0.012\end{array}$ & $\begin{array}{l}0.959 \\
0.003\end{array}$ & $\begin{array}{l}0.920 \\
0.009\end{array}$ \\
\hline \multirow[t]{3}{*}{$\begin{array}{l}\text { Day } 8 \\
\text { p.i. }\end{array}$} & $\begin{array}{l}\text { TNF- } \alpha \\
(\mathrm{pg} / \mathrm{mL})\end{array}$ & $\begin{array}{c}0.983 \\
<0.01^{\mathrm{a}}\end{array}$ & $\begin{array}{l}0.839 \\
0.037\end{array}$ & $\begin{array}{l}0.915 \\
0.011\end{array}$ & $\begin{array}{l}0.938 \\
0.006\end{array}$ & $\begin{array}{l}0.973 \\
0.001\end{array}$ & $\begin{array}{l}0.962 \\
0.002\end{array}$ \\
\hline & $\begin{array}{l}\text { IL-6 } \\
\text { (pg/mL) }\end{array}$ & $\begin{array}{l}0.968 \\
0.002\end{array}$ & $\begin{array}{l}0.820 \\
0.046\end{array}$ & $\begin{array}{l}0.981 \\
0.001\end{array}$ & $\begin{array}{l}0.960 \\
0.002\end{array}$ & $\begin{array}{l}0.982 \\
<0.01^{\mathrm{a}}\end{array}$ & $\begin{array}{l}0.922 \\
0.009\end{array}$ \\
\hline & $\begin{array}{l}\text { IL-1 } \beta \\
(\mathrm{pg} / \mathrm{mL})\end{array}$ & $\begin{array}{l}0.978 \\
0.001\end{array}$ & $\begin{array}{l}0.828 \\
0.042\end{array}$ & $\begin{array}{l}0.980 \\
0.001\end{array}$ & $\begin{array}{l}0.959 \\
0.002\end{array}$ & $\begin{array}{l}0.992 \\
<0.01^{\mathrm{a}}\end{array}$ & $\begin{array}{l}0.935 \\
0.006\end{array}$ \\
\hline \multirow[t]{3}{*}{$\begin{array}{l}\text { Day } 12 \\
\text { p.i. }\end{array}$} & $\begin{array}{l}\text { TNF- } \alpha \\
(\mathrm{pg} / \mathrm{mL})\end{array}$ & $\begin{array}{c}-0.518 \\
0.293\end{array}$ & $\begin{array}{l}0.396 \\
0.473\end{array}$ & $\begin{array}{l}0.665 \\
0.149\end{array}$ & $\begin{array}{c}-0.154 \\
0.771\end{array}$ & $\begin{array}{l}0.586 \\
0.222\end{array}$ & $\begin{array}{c}-0.501 \\
0.311\end{array}$ \\
\hline & $\begin{array}{l}\text { IL-6 } \\
\text { (pg/mL) }\end{array}$ & $\begin{array}{c}-0.784 \\
0.065\end{array}$ & $\begin{array}{l}-0625 \\
0.184\end{array}$ & $\begin{array}{r}-0.623 \\
0.187\end{array}$ & $\begin{array}{c}-0702 \\
0.120\end{array}$ & $\begin{array}{l}-0.583 \\
0.224\end{array}$ & $\begin{array}{r}-0.459 \\
0.359\end{array}$ \\
\hline & $\begin{array}{l}\text { IL-1 } \beta \\
(\mathrm{pg} / \mathrm{mL})\end{array}$ & $\begin{array}{l}-0.580 \\
0.227\end{array}$ & $\begin{array}{l}-0.726 \\
0.102\end{array}$ & $\begin{array}{l}-0.493 \\
0.323\end{array}$ & $\begin{array}{c}-0.684 \\
0.134\end{array}$ & $\begin{array}{l}-0.423 \\
0.403\end{array}$ & $\begin{array}{r}-0.641 \\
0.170\end{array}$ \\
\hline
\end{tabular}

${ }^{\text {a }}$ Correlation is significant at the 0.01 level (2-tailed)

limb weakness, and limb paralysis prior to death. Similar to human manifestations of EV71 encephalomyelitis [11], the virus exhibited a strong tropism for the CNS of ICR mice, with the numbers of viral RNA copies in CNS (brainstem, brain, spinal cord and cerebellum) were higher than in lung or/and heart, especially, in brainstem and brain higher than other tissues coinciding with the severity or even death of the animals. In addition, all sick mice exhibited massive neuronal damage, increased levels of cytokines, as reported previously for severe cases of human EV71 disease [35].

In this study, we found that the expression of mSCARB2 moderately increased in CNS, lung and heart in EV71 (BrCr)infected mice, and the expression of mSCARB2 was higher in CNS than in lung or/and heart at day 4 p.i., especially, in brainstem and brain, and at day 8 and 12 , the expression of mSCARB2 decreased. The TNF- $\alpha$, IL- 6 and IL- $1 \beta$ production significantly increased in the CNS of EV71 infected mice in comparison with lung and heart at day 4 p.i.. At day 8 and 12 p.i., the levels of TNF- $\alpha$, IL- 6 and IL-1 $\beta$ production decreased. Interestingly, the expression of $\mathrm{mSCARB} 2$ in various tissues of EV71-infected mice has the similar trend to the production of TNF- $\alpha$, IL-6 and IL-1 $\beta$. Surprisingly, our data revealed a positive correlation between relative mSCARB2 $m R N A$ level and TNF- $\alpha$, IL- 6 and IL-1 $\beta$ levels in local tissues at day 4 p.i. and at day 8 p.i., but at day 12 p.i., it showed no correlation.

Carrasco-Marín E et al., presented evidence for the specific role of LIMP-2/SCARB2 in the innate immune response to Listeria monocytogenes and in phagocytosis. LIMP-2 tightly controls the number of cytosolic LM and the induction of acute phase pro-inflammatory cytokines such as MCP-1, TNF-a, and IL-6. However, the production of late pro-inflammatory 
cytokines, such as INF- $\gamma$ and IL10, was not regulated by LIMP-2/SCARB2 [24]. In infection, two cytokines involved in macrophages (M $\varnothing$ ) activation: TNF- $\alpha$ and INF- $\gamma$. TNF- $\alpha$ acts as an early signal in innate immunity, INF- $\gamma$ is a late signal. It has been claimed that exogenous action of TNF-a promotes an early activating state in $M \varnothing$ s that triggers the cytosolic microbicidal mechanisms [36-38]. In EV71 infection, SCARB2 may also participates in exogenous $M \varnothing$ activation, the early signals modulated by TNF-a.

Taken together, we assumed that in EV71 infected mice, the elevated local mSCARB2 may regulate the early innate immune response to EV71, or even modulate pro-inflammatory cytokines induction; mSCARB2 may also act as the invasive receptor for the enterovirus 71 although no experimental evidence has ever been provided support this hypotheses, because human SCARB2 (hSCARB2) have been identified as cellular receptors for EV71, and mSCARB2 exhibited $85.8 \%$ amino acid identity and $99.9 \%$ similarity to hSCARB2 $[39,40]$; the elevated expression of mSCARB2 in EV71-infected mice may play other roles, which are not clear now.

\section{Competing interests}

The authors declare that they have no competing interests.

\section{Authors' contributions}

\begin{tabular}{|l|c|c|}
\hline Authors' contributions & JL & ZC \\
\hline Research concept and design & $\checkmark$ & $\checkmark$ \\
\hline Collection and/or assembly of data & $\checkmark$ & -- \\
\hline Data analysis and interpretation & $\checkmark$ & $\checkmark$ \\
\hline Writing the article & $\checkmark$ & -- \\
\hline Critical revision of the article & $\checkmark$ & $\checkmark$ \\
\hline Final approval of article & -- & $\checkmark$ \\
\hline Statistical analysis & $\checkmark$ & -- \\
\hline
\end{tabular}

\section{Acknowledgement}

This study was financially supported by grants from the Natural Science of China (no. 31171212).

Publication history

EIC: Eric Triplett, University of Florida, USA.

Received: 15-Jan-2014 Revised: 09-Feb-2014

Accepted: 13-Feb-2014 Published: 28-Feb-2014

\section{References}

1. Alexander JP, Jr., Baden L, Pallansch MA and Anderson LJ. Enterovirus $\mathbf{7 1}$ infections and neurologic disease--United States, 1977-1991. J Infect Dis. 1994; 169:905-8. | Article | PubMed

2. Chan KP, Goh KT, Chong CY, Teo ES, Lau G and Ling AE. Epidemic hand, foot and mouth disease caused by human enterovirus 71 , Singapore. Emerg Infect Dis. 2003; 9:78-85. | Article | PubMed Abstract | PubMed Full Text

3. Ahmad K. Hand, foot, and mouth disease outbreak reported in Singapore. Lancet. 2000; 356:1338. | Article | PubMed

4. Shah VA, Chong CY, Chan KP, Ng W and Ling AE. Clinical characteristics of an outbreak of hand, foot and mouth disease in Singapore. Ann Acad Med Singapore. 2003; 32:381-7. | Article | PubMed

5. Jee YM, Cheon DS, Kim K, Cho JH, Chung YS, Lee J, Lee SH, Park KS, Lee
JH, Kim EC, Chung HJ, Kim DS, Yoon JD and Cho HW. Genetic analysis of the VP1 region of human enterovirus 71 strains isolated in Korea during 2000. Arch Virol. 2003; 148:1735-46. | Article | PubMed

6. Chan LG, Parashar UD, Lye MS, Ong FG, Zaki SR, Alexander JP, Ho KK, Han LL, Pallansch MA, Suleiman AB, Jegathesan M and Anderson LJ. Deaths of children during an outbreak of hand, foot, and mouth disease in sarawak, malaysia: clinical and pathological characteristics of the disease. For the Outbreak Study Group. Clin Infect Dis. 2000; 31:678-83. | Article | PubMed

7. Fujimoto T, Chikahira M, Yoshida S, Ebira H, Hasegawa A, Totsuka A and Nishio $O$. Outbreak of central nervous system disease associated with hand, foot, and mouth disease in Japan during the summer of 2000: detection and molecular epidemiology of enterovirus 71. Microbiol Immunol. 2002; 46:621-7. | Article | PubMed

8. Tu PV, Thao NT, Perera D, Huu TK, Tien NT, Thuong TC, How OM, Cardosa $\mathrm{MJ}$ and McMinn PC. Epidemiologic and virologic investigation of hand, foot, and mouth disease, southern Vietnam, 2005. Emerg Infect Dis. 2007; 13:1733-41. | Article | PubMed Abstract | PubMed Full Text

9. Wang JR, Tuan YC, Tsai HP, Yan JJ, Liu CC and Su IJ. Change of major genotype of enterovirus 71 in outbreaks of hand-foot-and-mouth disease in Taiwan between 1998 and 2000. J Clin Microbiol. 2002; 40:105. | Article | PubMed Abstract | PubMed Full Text

10. Zhang Y, Tan XJ, Wang HY, Yan DM, Zhu SL, Wang DY, Ji F, Wang XJ, Gao YJ, Chen L, An HQ, Li DX, Wang SW, Xu AQ, Wang ZJ and Xu WB. An outbreak of hand, foot, and mouth disease associated with subgenotype C4 of human enterovirus 71 in Shandong, China. J Clin Virol. 2009; 44:262-7. I Article | PubMed

11. Huang CC, Liu CC, Chang YC, Chen CY, Wang ST and Yeh TF. Neurologic complications in children with enterovirus 71 infection. $N$ Engl J Med. 1999; 341:936-42. | Article | PubMed

12. Wang SM, Liu CC, Tseng HW, Wang JR, Huang CC, Chen YJ, Yang YJ, Lin SJ and Yeh TF. Clinical spectrum of enterovirus 71 infection in children in southern Taiwan, with an emphasis on neurological complications. Clin Infect Dis. 1999; 29:184-90. | Article | PubMed

13. Wang YF, Chou CT, Lei HY, Liu CC, Wang SM, Yan JJ, Su IJ, Wang JR, Yeh TM, Chen SH and Yu CK. A mouse-adapted enterovirus 71 strain causes neurological disease in mice after oral infection. J Virol. 2004; 78:791624. | Article | PubMed Abstract | PubMed Full Text

14. Wang W, Duo J, Liu J, Ma C, Zhang L, Wei Q and Qin C. A mouse muscleadapted enterovirus $\mathbf{7 1}$ strain with increased virulence in mice. Microbes Infect. 2011; 13:862-70. | Article | PubMed

15. Khong WX, Yan B, Yeo H, Tan EL, Lee JJ, Ng JK, Chow VT and Alonso $S$. A non-mouse-adapted enterovirus 71 (EV71) strain exhibits neurotropism, causing neurological manifestations in a novel mouse model of EV71 infection. J Virol. 2012; 86:2121-31. | Article | PubMed Abstract | PubMed Full Text

16. Hashimoto I, Hagiwara A and Kodama H. Neurovirulence in cynomolgus monkeys of enterovirus 71 isolated from a patient with hand, foot and mouth disease. Arch Virol. 1978; 56:257-61. | Article I PubMed

17. Zhang G, Zhou F, Gu B, Ding C, Feng D, Xie F, Wang J, Zhang C, Cao Q, Deng $\mathrm{Y}, \mathrm{Hu} \mathrm{W}$ and $\mathrm{Yao} \mathrm{K}$. In vitro and in vivo evaluation of ribavirin and pleconaril antiviral activity against enterovirus 71 infection. Arch Virol. 2012; 157:669-79. | Article | PubMed

18. Calvo D, Dopazo J and Vega MA. The CD36, CLA-1 (CD36L1), and LIMPII (CD36L2) gene family: cellular distribution, chromosomal location, and genetic evolution. Genomics. 1995; 25:100-6. | Article | PubMed

19. Eskelinen EL, Tanaka $Y$ and Saftig P. At the acidic edge: emerging functions for lysosomal membrane proteins. Trends Cell Biol. 2003; 13:137-45. | Article | PubMed

20. Kuronita T, Eskelinen EL, Fujita H, Saftig P, Himeno M and Tanaka Y. A role for the lysosomal membrane protein LGP85 in the biogenesis and maintenance of endosomal and lysosomal morphology. J Cell Sci. 2002; 115:4117-31. | Article | PubMed

21. Blanz J, Groth J, Zachos C, Wehling C, Saftig P and Schwake M. Diseasecausing mutations within the lysosomal integral membrane protein type 2 (LIMP-2) reveal the nature of binding to its ligand beta- 
glucocerebrosidase. Hum Mol Genet. 2010; 19:563-72. | Article | PubMed

22. Gamp AC, Tanaka Y, Lullmann-Rauch R, Wittke D, D'Hooge R, De Deyn PP, Moser T, Maier H, Hartmann D, Reiss K, Illert AL, von Figura K and Saftig P. LIMP-2/LGP85 deficiency causes ureteric pelvic junction obstruction, deafness and peripheral neuropathy in mice. Hum Mol Genet. 2003; 12:631-46. | Article | PubMed

23. Berkovic SF, Dibbens LM, Oshlack A, Silver JD, Katerelos M, Vears DF, Lullmann-Rauch R, Blanz J, Zhang KW, Stankovich J and Kalnins RM et al. Array-based gene discovery with three unrelated subjects shows SCARB2/LIMP-2 deficiency causes myoclonus epilepsy and glomerulosclerosis. Am J Hum Genet. 2008; 82:673-84. | Article | PubMed Abstract | PubMed Full Text

24. Carrasco-Marin E, Fernandez-Prieto L, Rodriguez-Del Rio E, MadrazoToca F, Reinheckel T, Saftig P and Alvarez-Dominguez C. LIMP-2 links late phagosomal trafficking with the onset of the innate immune response to Listeria monocytogenes: a role in macrophage activation. J Biol Chem. 2011; 286:3332-41. | Article | PubMed Abstract | PubMed Full Text

25. Lin TY, Chang LY, Huang YC, Hsu KH, Chiu CH and Yang KD. Different proinflammatory reactions in fatal and non-fatal enterovirus $\mathbf{7 1}$ infections: implications for early recognition and therapy. Acta Paediatr. 2002; 91:632-5. | Article | PubMed

26. Lin TY, Hsia SH, Huang YC, Wu CT and Chang LY. Proinflammatory cytokine reactions in enterovirus 71 infections of the central nervous system. Clin Infect Dis. 2003; 36:269-74. | Article | PubMed

27. Wang SM, Lei HY, Su LY, Wu JM, Yu CK, Wang JR and Liu CC. Cerebrospinal fluid cytokines in enterovirus 71 brain stem encephalitis and echovirus meningitis infections of varying severity. Clin Microbiol Infect. 2007; 13:677-82. | Article | PubMed

28. Wang SM, Lei HY, Huang KJ, Wu JM, Wang JR, Yu CK, Su IJ and Liu CC Pathogenesis of enterovirus 71 brainstem encephalitis in pediatric patients: roles of cytokines and cellular immune activation in patients with pulmonary edema. J Infect Dis. 2003; 188:564-70. | Article | PubMed

29. Weng KF, Chen LL, Huang PN and Shih SR. Neural pathogenesis of enterovirus 71 infection. Microbes Infect. 2010; 12:505-10. | Article | PubMed

30. Khong WX, Foo DG, Trasti SL, Tan EL and Alonso S. Sustained high levels of interleukin- 6 contribute to the pathogenesis of enterovirus 71 in a neonate mouse model. J Virol. 2011; 85:3067-76. | Article | PubMed Abstract | PubMed Full Text

31. Reed $\mathrm{LJ}$ and Muench $\mathrm{H}$. A simple method of estimating fifty percent endpoint. Am J Hyg. 1938; 27:493-7. | Article

32. Lin YW, Chang KC, Kao CM, Chang SP, Tung YY and Chen SH. Lymphocyte and antibody responses reduce enterovirus 71 lethality in mice by decreasing tissue viral loads. J Virol. 2009; 83:6477-83. | Article | PubMed Abstract | PubMed Full Text

33. Yang CF, De L, Yang SJ, Ruiz Gomez J, Cruz JR, Holloway BP, Pallansch MA and Kew OM. Genotype-specific in vitro amplification of sequences of the wild type 3 polioviruses from Mexico and Guatemala. Virus Res. 1992; 24:277-96. | Article | PubMed

34. Jiang MH, Fei J, Lan MS, Lu ZP, Liu M, Fan WW, Gao X and Lu DR. Hypermethylation of hepatic Gck promoter in ageing rats contributes to diabetogenic potential. Diabetologia. 2008; 51:1525-33. | Article | PubMed

35. Ooi MH, Wong SC, Lewthwaite P, Cardosa MJ and Solomon T. Clinical features, diagnosis, and management of enterovirus 71. Lancet Neurol. 2010; 9:1097-105. | Article | PubMed

36. Pamer EG. Immune responses to Listeria monocytogenes. Nat Rev Immunol. 2004; 4:812-23. | Article | PubMed

37. Zenewicz LA and Shen $\mathrm{H}$. Innate and adaptive immune responses to Listeria monocytogenes: a short overview. Microbes Infect. 2007; 9:1208-15. | Article | PubMed Abstract | PubMed Full Text

38. Edelson BT and Unanue ER. MyD88-dependent but Toll-like receptor 2-independent innate immunity to Listeria: no role for either in macrophage listericidal activity. J Immunol. 2002; 169:3869-75. | Article I PubMed

39. Yamayoshi S, Yamashita Y, Li J, Hanagata N, Minowa T, Takemura T and Koike S. Scavenger receptor B2 is a cellular receptor for enterovirus $\mathbf{7 1}$ Nat Med. 2009; 15:798-801. | Article | PubMed

40. Yamayoshi $S$ and Koike S. Identification of a human SCARB2 region that is important for enterovirus $\mathbf{7 1}$ binding and infection. J Virol. 2011; 85:4937-46. | Article | PubMed Abstract | PubMed Full Text

\section{Citation:}

$\mathrm{Li} \mathrm{J-a}$ and Chen Z-b. The expression of scavenger receptor $\mathrm{B} 2$ in enterovirus 71-infected mice. J Mol Eng Syst Biol. 2014; 3:1. http://dx.doi.org/10.7243/2050-1412-3-1 